\title{
Martins, Swallows and Sparrows
}

Cecilia L. Hill, Nanaimo, Vancouver Island

IN the January to March edition of "The Blue Jay," Mr. J. Isinger asks if anyone can substantiate the story that Martins will plaster intruding Sparrows in their nests.

I well remember my grandfather in the old country knocking down Martins' nests which had been taken over by Sparrows. He told me the Martins plastered up any nests taken over by the Sparrow's with the Sparrows in them. Year after year the House Martins returned to nest under the overhanging eaves on his twostory home on the north side, and each year grandfather with his long pole removed nests with intruding Sparrows.

I looked up House Martins in $\mathrm{J}$. Lewis Bonhote's "Birds of Britain" and found their Latin name was Chelidon urbica, (Lunnaeus) whereas the Purple Martin in Travener's "Birds of Western Canada" is Progne subis. Both books mention that Sparrows will take over the nests of either species but neither mention that Martins will plaster them in. Would it be possible to plaster up the entrance to a bird house as easily as the one to a mud nest?

We had an in'eresting experience with Barn Swallows in Manitoba some years ago. Each year a pair built a nest in the cow barn but one summer morning my husband found the nest and tiny birds had fallen on the floor and the parents were flying around in great distress. He nailed a small strawberry basket on the beam where the nest had been and put the little fellows into it and hoped for the best. To our great joy the parents coritinued caring for them and shortly after the wee fellows clambered on to the edge of the basket, and remained monarchs of all they surveyed till they were ready to fly.

\section{Bird Migrants and Visitors in April Cecilia L. Hill, Nanaimo, Vancouver Island}

UNFORTUNATELY I did not make a note of the date we heard the first geese going north but during April I have noted a few migrants and their date of arrival. We are later here than in Victoria also though we saw Swallows first on April 2nd. They were reported in the south end of the district nearly a week earlier.

The first Rufus Hummingbird was noticed April 4th working on the peach blossom and since they have been very busy on the wild currant. The female was a few days later in arriving.

The next migrant noted was the White Crowned Sparrow on April 10, then on the 11th an Audubon's Warbler both male and female were seen. The male stayed cver for a bath and one has been here again this week making a nice splash of colour amongst the early green leaves. It is the first time I have seen this species here.

Several Goldfinches stopped a short time on April 22nd but they must have been on their way further north as I have not seen them since. Usually they are about our last migrants to stay, it has always appeared to me.

The Robins were collecting nesting material on March 7 th but I have not observed them carrying worms so far though they have been collecting nesting material again as though their first efforts have not been crowned with success. Pine Siskins have been gathering nesting materials at two different times. They come quite frequently to drink and pull off the plum blossoms, it seems. A Chickadee came for resting material on April 5th, some fluff swept out of the house and it seemed most particular in the way it combed it this way and that before flying away.

Purple Finches came occasionally right through the year. We have had a few other migrants who have not stayed long enough for certain identification. More birds are coming now that our trees are growing up and with water always available they are finding it more attractive, we hope. (Continued on Page 16) 